\title{
Oil theft and insecurity in post amnesty era in the Niger Delta Region of Nigeria: Implications on national security
}

\author{
Boris Happy Odalonu \\ Federal College of Education, P.M.B. 2001 Eha-Amufu, Enugu State, Nigeria \\ Email: boris2nice@gmail.com Phone: +2348034866385
}

Accepted 12 June, 2016

\begin{abstract}
The Amnesty programme for Niger Delta militants was introduced in 2009 to curb militancy, oil theft and insecurity in the Niger Delta region. Five years after, the rate of oil theft and insecurity in the region seems to be on increase which poses serious security challenges on Nigerian state. This paper examines the issues of oil theft and insecurity in post amnesty era in the Niger Delta region of Nigeria and its implication for national security. Secondary data was employed in the study and the paper identifies that the grave issues (unemployment, land degradation, resource control, underdevelopment, poverty) that led to militancy which resulted in oil theft and criminalities in the Niger Delta have not been addressed and thus, the Amnesty Programme is just a palliative measure. In the light of the above the paper recommends that the stolen oil trade problem must be tackled at its source which is unemployment and poverty
\end{abstract}

Keywords: Post-Amnesty, Oil theft, insecurity, National security, Niger Delta, Nigeria

\section{INTRODUCTION}

Few years ago the Niger Delta region, the hub of Nigeria's oil and gas production was almost ungovernable. Hostage-taking of foreign oil workers, sabotage of oil pipelines and other petroleum production facilities as well as other vices were the order of the day. Militants in Nigeria's oil-rich Niger Delta began a campaign of kidnappings and pipeline bombings in the early 2000s, upset over pollution and the region's endemic poverty. After a government-sponsored amnesty program in 2009, violence dropped and production went back up. But oil theft, a lucrative criminal industry, has drawn many militants new and old back into the delta's winding creeks. While richly remunerated former kingpins profess to have left the oil-theft business, many former militant foot soldiers that are paid less or not at all by the amnesty, and have few job prospects, continue to pursue prosperity by tapping pipelines (Hinshaw, 2012).

Now, oil theft appears to be on the rise again. Oil theft and illegal bunkering have greatly increased-and piracy seems to be an important aspect of it. More than 300,000 barrels of oil are stolen from Nigerian pipelines daily (Akpan 2013; Olusola, 2013; Odemwingie and NdaIsaiah, 2013; Okere, 2013). While stories of kidnapping still abound, they are more common in other parts of the country where they have become a new industry as against, the earlier agitation in the Niger Delta region. Illegal oil bunkering has been an economic and security problem in Nigeria since the 80 s and government over the years has also been putting measures in place to check it (Nwanosike, 2013). But despite all the measures undertaken by the government, crude oil theft continues to increase in scope and dimension. Oil is the major catalyst that derives the Nigerian economy and by implication the determinant of its entire socio-political configuration. Consequently, anything that covertly or overtly affects oil production in Nigeria poses a direct threat to her national economy, political stability, territorial integrity and national security.

\section{Aim and background of the study}

This paper is focus on the issues of oil theft and insecurity in post amnesty era in the Niger Delta region of Nigeria and its implication on national security. The paper attempts to examine the nexus between oil theft 
and insecurity in the Niger Delta, the implications of oil theft on Nigeria's national security and the attempts at tackling oil theft by the government. Secondary data was employed in this study and the setting was the Niger Delta region of Nigeria.

The Niger Delta region is made up of 9 political states with different ethnic groups. The states are Rivers, Imo, Abia, Akwa lbom, Ondo, Edo, and Cross River. The states are the oil producing states in Nigeria (Wilson, 2014). The region is blessed with several natural resources, including huge crude oil deposit. It has been the main crude oil production base of Nigeria (Akpomera, 2013). The region is the world's third largest wet land and largest in Africa, with an area of about 70,000 sq kilometer, an ecological zone of large rivers, coastal areas, mangroves, and fresh and salt water swamp forest (Badmus, 2010; Fagbadebo and Akinola, 2010; Wilson, 2014).

The Niger Delta region has 5,700 oil well, 112 flow stations, 16 gas plants, 126 production platforms, 6 floating production storage offloading platforms, 13 oil terminals, and 6,000 kilometers of pipelines (Wilson, 2014). The region holds $95 \%$ of Nigerian oil reserves which account for $90 \%$ of Nigerian government revenue and $95 \%$ of its export receipts (Ikelegbe, 2005; Ikein, 2009)). Despite these impressive figures, the region is one of the poorest and least developed in Nigeria. The Niger Delta region of Nigeria has been engulfed by oilrelated conflict for over two decades now, and concerns pertaining to Nigeria's national security, economic stability, and global energy security have been brought to the fore of global discourse.

\section{Crude Oil Theft and insecurity in the Niger Delta}

Oil theft is the act of stealing crude oil from the pipelines or flow stations, as well as extra crude oil added to legitimate cargos that are not accounted for (Asuni, 2009). Oil theft also known as illegal oil bunkering has been the main source of stealing crude oil in the Niger Delta region for both domestic and export consumptions (Wilson, 2014). According to Ayanruoh (2013) illegal oil bunkering is the "process through which crude oil or refined petroleum products are illegally siphoned from pipelines and sold to interested dealers waiting on the high sea or the unscrupulous individual. The most popular method for stealing the crude oil is to puncture the pipeline conveying the product from one point to the other and tap it at the point where it had been punctured or ruptured (Adegbite, 2013). The bunkerers "tap directly into pipelines away from oil company facilities, and connect from the pipelines to barges that are hidden in small creeks with mangrove forest cover" (Human Rights Watch 2003).

Crude oil theft in the Niger Delta remains a serious cause for concern with dire consequences for people, the environment and the economy. This highly sophisticated criminal activity involving local and international crime syndicates, pollutes rivers, blights farmlands, destroys livelihoods and promotes general insecurity and poverty in an already fragile environment. For over a decade, vandals of oil pipelines and Nigeria's crude oil thieves have been in business uninterrupted. These criminal activities have left an indelible mark on the country's ailing economy. This is because oil and gas remain the major sources of national revenue as well as foreign earnings for over 50 years since oil was discovered (Mernyi, 2014). Several times, government had declared total war on these economic saboteurs but they kept improving on their activities. The more government with the aid of security agencies devised means of protecting the oil facilities particularly in the Niger Delta, the more the actors improve on their operations to beat even the modern technologies used in fortifying the oil pipelines and installations (Mernyi, 2014).

What it takes the well organized syndicated crime gangs involved in the business to sustain the flow of the commodity is to plug back a part of the proceeds from the stolen crude oil into weapon acquisition to fan the conflicts (Garuba, 2010). Apart from outright insecurity that the foregoing situation poses to the Niger Delta region and the entire country, the huge profit of the illegal private business also translates into incalculable loss to the Nigerian state which owns $55 \%$ in the joint venture with Shell Petroleum Development Company (SPDC), TotalFinaElf and Agip - the direct victims of criminality (Garuba, 2010).

According to Odunlami et al. (2013) there are two legs to the illicit oil theft trade. On the big, international multidollar platform are powerful Nigerians who can afford to buy or hire the big vessels used in illegal crude oil bunkering. The untouchable thieves illegally load crude onto their own or hired ships and sail to the waters off Nigeria where the buying foreign merchants from West Africa and Eastern Europe await them. Mostly, in these illegal deals, compromised security agents, at the behest of the highly influential Nigerians involved in the trade, look the other way while the ships sail away.

There are also the daring pirates, now involving many young and middle-aged Nigerians, who operate in the Gulf of Guinea and hijack fuel tankers. But rather than demand for ransom for the crew as was initially done by Niger Delta militants, they now load the hijacked product onto their ships to sell to the ready and lucrative foreign black market on the West Africa coast and in European countries like Russia (Odunlami et al., 2013).

Thus, the activities of oil theft in the Niger Delta region of Nigeria are clearly a sophisticated organization. It involves different personalities such as; the oil company personnel, the military officer, the politicians, the local communities, the international oil trader, militants, shippers, bankers, refiners, wealthy individuals from within and outside Nigeria. The level of involvement in oil 
theft in the Niger Delta region of Nigeria by foreigners and Nigerians is indicated in the table of some incidence of oil theft arrests in Nigeria below;

Most of these arrests were made off the coast of the Niger Delta; Bonny Island in Rivers State, Nun River, Forcados Rivers, Escravos, Brass River, Akassa River, Benin River, Dodo River and Lagos Offshore Base. Some others have also been made on the high sea. It is adduced that apart from initial celebration of cases of arrest in the media, very little or nothing is heard about what eventually happened to arrested cargoes and suspects, as successful prosecutions are least undertaken (Garuba, 2010). The Commanding Officer of the Nigerian Naval Ship (NNS) Pathfinder, Port Harcourt, Commodore Oyetunji Fadeyi, alluded to this fact when he disclosed in January 2014, that the government has not jailed bunkerers so far due to involvement of highly influential personalities in the society. He lamented that:

"Since I came on board as commanding officer of NNS Pathfinder, it has been tough, especially with illegal bunkering and many persons arrested over illegal products and handed over to the Economic and Financial Crimes Commission (EFCC) for prosecution, but surprisingly, not even one person has been successfully prosecuted," (Mernyi, 2014).

This shows that oil bunkering and pipeline vandalism continued to thrive in Nigeria, in spite of government's efforts, because of some vested interest of powerful persons involved in the business and the lack of the political will to deal with it (Mernyi, 2014). The pace of arrests of oil thieves in recent years illustrates the gravity of the issues at hand. The Nigerian government was largely helpless in the face of the relentless vandalisation of pipelines, which posed a major threat to the fledgling amnesty scheme and to national security. Long years of neglect, underdevelopment, inequity and unfairness have given rise to grievance by the people of Niger Delta and this has been the major root cause of insecurity in the region. Consequently large numbers of the Niger Delta people have become frustrated and lost hope, particularly the youths who have taken to violence (Afinotan and Ojakorotu, 2009; Kimiebi, 2010; Ibaba, 2011; Aminu, 2013). Investigations showed that the security agencies may not be able to completely arrest pipeline vandalism and oil theft because of many reasons, especially the difficult location of illegal oil operations in the Niger Delta (Akpan, 2013). This poses great danger for peace and security in the Niger Delta region and the entire country.

Indeed, widespread illegal bunkering has led to control by armed bands over large areas in the oil-producing states. While some armed groups claimed political objectives, others remained openly criminal; all armed groups intimidated and dominated the communities in the territory they controlled thereby undermining traditional leadership and social structures (Onwuemenyi, 2012). Although Nigeria is still recovering from the Niger Delta insurgency, the Boko Haram insurgency in the north has created a high sense of insecurity throughout the country.

The huge expenditure on security has not translated into peace and security. Therefore, there is an urgent need to re-examine the approach to peace and security in the country as this may promote social political development (Ejovi and Ebie, 2013). This is because, any environment inundated with crime and insecurity is always accompanied with tensions and anxiety. The elimination of these threats and enemies of man should be the number one programme of the governments in Nigeria. This will give rise to human development and a habitable environment for us all.

From the foregoing, what is clear is that continuing alienation, corruption, environmental degradation and unemployment could further boost insecurity in the Niger Delta region. Therefore, the stolen oil trade problem must be tackled at its source which is unemployment and poverty. There must be a partnership between the Nigerian government and the international community to invest more and expand the legitimate oil sector. This would provide more opportunities for the local community which could benefit from their regions rich oil resources without resorting to theft. Legitimizing and improving many of the illegal oil refineries by bringing them under the management of oil companies could also be a viable option.

\section{National Security}

The concept of national security can be widely interpreted to mean many similar things or situations by different scholars and analysts; hence there is no universally accepted definition of national security. The variety of definitions provides an overview of the many usages of this concept. However in the context of this paper national security may be refers to the absence of threats to core values and the prevention of public disorders. On the other hand, insecurity is the presence of and/or apprehension of those tendencies that could undermine internal cohesion and corporate existence of the nation and its ability to maintain its vital institutions for the promotion of its core values and socio-political objectives, as well as meet the legitimate aspirations of the people (Robert-Okah, 2014). It also implies the presence or apprehension of danger to life and property, and the presence of a non-conducive atmosphere for the people to pursue their legitimate interest within the society (Robert-Okah, 2014).

Traditionally, national security was seen as the capability of a nation to enforce its policy choices by use of military force; the struggle of states to overcome various external and internal threats. Conversely, national security cannot be equated to military might, defence or law enforcement alone. It goes beyond all of that to accommodate far more reaching issues. In short, national security is the ability of a state to overcome any of its 
Table 1: some incidence of oil theft arrests in Nigeria 2009-2014

\begin{tabular}{|c|c|c|c|c|c|}
\hline $\begin{array}{l}\text { DATE OF } \\
\text { ARREST }\end{array}$ & VESSEL & $\begin{array}{c}\text { PEOPLE } \\
\text { INVOLVED }\end{array}$ & $\begin{array}{l}\text { PLACE OF } \\
\text { ARREST }\end{array}$ & $\begin{array}{c}\text { REASON FOR } \\
\text { ARREST } \\
\end{array}$ & $\begin{array}{l}\text { ARRESTED BY \& } \\
\text { ACTION TAKEN. }\end{array}$ \\
\hline August 25, 2014. & MV MERCY & $\begin{array}{l}\text { Seven Crew } \\
\text { Members }\end{array}$ & $\begin{array}{l}\text { The Furopa } \\
\text { waterways in } \\
\text { Southern ljaw } \\
\text { Local Government } \\
\text { Area of Bayelsa }\end{array}$ & $\begin{array}{l}\text { Vessel loaded with } \\
180,000 \text { litres of } \\
\text { illegally refined } \\
\text { Automated Gas Oil } \\
\text { (diesel) worth N28.8 } \\
\text { million }\end{array}$ & $\begin{array}{l}\text {.The suspects and } \\
\text { vessel and were } \\
\text { arrested by Nigerian } \\
\text { Navy and handed over } \\
\text { to the Nigerian } \\
\text { Security and Civil } \\
\text { Defence Corps for } \\
\text { further investigation } \\
\text { and prosecution. }\end{array}$ \\
\hline August 7, 2014. & MV ELMINA & $\begin{array}{l}18 \text { Nigerians, one } \\
\text { Camerounian and } \\
\text { one Ghanaian }\end{array}$ & $\begin{array}{l}\text { Sangana River in } \\
\text { Brass Local } \\
\text { Government of } \\
\text { Bayelsa State. }\end{array}$ & $\begin{array}{l}\text { Allegedly stealing } \\
500,000 \text { litres of } \\
\text { crude oil. }\end{array}$ & $\begin{array}{l}\text { The suspects were } \\
\text { arrested by Nigerian } \\
\text { Navy and handed over } \\
\text { to EFCC }\end{array}$ \\
\hline April 19, 2014. & $\begin{array}{l}\text { MT } \\
\text { RHEINFELD } \\
\text { EN }\end{array}$ & One crew member & $\begin{array}{l}\text { Akassa } \\
\text { Community in } \\
\text { Brass L.G.A of } \\
\text { Bayelsa state. }\end{array}$ & $\begin{array}{l}\text { The vessel was } \\
\text { laden with } 849,612 \\
\text { tonnes of illegally } \\
\text { refined automotive } \\
\text { gas oil }\end{array}$ & $\begin{array}{l}\text { The suspects were } \\
\text { arrested by Nigerian } \\
\text { Navy and handed over } \\
\text { to EFCC. }\end{array}$ \\
\hline April 18, 2014 & MV FLORA & $\begin{array}{l}\text { Eight Crew } \\
\text { Member }\end{array}$ & $\begin{array}{l}\text { Lagosgbene Obi } \\
\text { creek in Southern } \\
\text { ljaw Local } \\
\text { Government Area } \\
\text { of Bayelsa State. }\end{array}$ & $\begin{array}{l}\text { Vessel laden with } \\
1,000 \text { litres of } \\
\text { suspected stolen } \\
\text { crude oil. }\end{array}$ & $\begin{array}{l}\text { The crew members } \\
\text { were arrested Joint } \\
\text { Task Force (JTF }\end{array}$ \\
\hline March 28, 2014 & MT CRETE & $\begin{array}{l}\text { Two Britons and } 12 \\
\text { Nigerian } \\
\text { technician }\end{array}$ & $\begin{array}{l}\text { Chanomi creek, } \\
\text { near Warri in } \\
\text { Delta state }\end{array}$ & $\begin{array}{l}\text { Involvement in illegal } \\
\text { bunkering and } \\
\text { offering of } \$ 66,500 \\
\text { bribe to the JTF to } \\
\text { facilitate oil theft. }\end{array}$ & $\begin{array}{l}\text { The suspects were } \\
\text { arrested by Joint Task } \\
\text { Force (JTF) and } \\
\text { handed over to the } \\
\text { Department of State } \\
\text { Security (DSS) for } \\
\text { prosecution. }\end{array}$ \\
\hline March 26, 2014. & MV GARE & $\begin{array}{l}\text { Three crew } \\
\text { members }\end{array}$ & $\begin{array}{l}\text { The coast of } \\
\text { Angola }\end{array}$ & $\begin{array}{l}\text { Vessel arrested for } \\
\text { hijacking and } \\
\text { stealing petroleum } \\
\text { products from a } \\
\text { bigger vessel - MV } \\
\text { Karela. }\end{array}$ & $\begin{array}{l}\text { Crew and vessel were } \\
\text { arrested by Nigerian } \\
\text { Navy and handed over } \\
\text { to the Interpol for } \\
\text { further investigation }\end{array}$ \\
\hline March 20, 2014. & $\begin{array}{l}\text { MT CERGEN } \\
\text { (whose } \\
\text { original name } \\
\text { was } \\
\text { MARISA) }\end{array}$ & $\begin{array}{l}\text { Six Nigerian crew } \\
\text { members. }\end{array}$ & $\begin{array}{l}\text { Around Fish Town } \\
\text { river in Southern } \\
\text { ljaw Local } \\
\text { Government Area } \\
\text { of Bayelsa State. }\end{array}$ & $\begin{array}{l}\text { The vessel was } \\
\text { loaded with } \\
2,332,000 \text { litres of } \\
\text { stolen crude oil }\end{array}$ & $\begin{array}{l}\text { The suspects were } \\
\text { arrested by Nigerian } \\
\text { Navy. }\end{array}$ \\
\hline $\begin{array}{l}\text { February 18, } \\
2014 .\end{array}$ & $\begin{array}{l}\text { LOCALLY } \\
\text { MADE TUG } \\
\text { BOAT }\end{array}$ & $\begin{array}{l}\text { Six crew member } \\
\text { and two others. }\end{array}$ & $\begin{array}{l}\text { Ajide on Benin } \\
\text { River in Edo } \\
\text { State. }\end{array}$ & $\begin{array}{l}\text { The boat was loaded } \\
\text { and conveying } 30 \\
\text { drums of stolen } \\
\text { petroleum. }\end{array}$ & $\begin{array}{l}\text { The six suspects were } \\
\text { arrested by Joint Task } \\
\text { Force (JTF) and } \\
\text { moved to the Tactical } \\
\text { Headquarters of the } \\
\text { Battalions for } \\
\text { preliminary } \\
\text { investigation. }\end{array}$ \\
\hline
\end{tabular}


Table 1. Cont.

\begin{tabular}{|c|c|c|c|c|c|}
\hline $\begin{array}{l}\text { February } 10, \\
2014 .\end{array}$ & $\begin{array}{l}\text { MT DIVINE } \\
\text { FAVOUR }\end{array}$ & 11 Crew Members & $\begin{array}{l}\text { Fairway Buoy, } \\
\text { Bonny Island, } \\
\text { Rivers State. }\end{array}$ & $\begin{array}{l}\text { The vessel had no } \\
\text { valid documents to } \\
\text { operate on Nigerian } \\
\text { waters and was } \\
\text { carrying about } 500 \\
\text { metric tonnes of } \\
\text { products suspected } \\
\text { to be Automated } \\
\text { Gasoline Oil (AGO). }\end{array}$ & $\begin{array}{l}\text { The suspects and the } \\
\text { vessel were arrested } \\
\text { by Nigerian Navy and } \\
\text { handed over to } \\
\text { operatives of the } \\
\text { Economic and } \\
\text { Financial Crimes } \\
\text { Commission (EFCC). }\end{array}$ \\
\hline $\begin{array}{l}\text { January 14, } \\
2014 .\end{array}$ & $\begin{array}{l}\text { MT ELI } \\
\text { TANK }\end{array}$ & $\begin{array}{l}21 \text { Nigerian crew } \\
\text { members }\end{array}$ & $\begin{array}{l}\text { Along the } \\
\text { waterways of } \\
\text { Agbami Oilfield in } \\
\text { Southern ljaw } \\
\text { Local } \\
\text { Government Area } \\
\text { of Bayelsa State. }\end{array}$ & $\begin{array}{l}\text { Vessel allegedly } \\
\text { loaded with } 2.111 \\
\text { million litres of } \\
\text { stolen crude oil } \\
\text { valued at N2.4bn. }\end{array}$ & $\begin{array}{l}\text { The suspects were } \\
\text { arrested by Nigerian } \\
\text { Navy }\end{array}$ \\
\hline $\begin{array}{l}\text { December 31, } \\
2013 .\end{array}$ & A Boat & $\begin{array}{l}\text { Four } \\
\text { Cameroonians and } \\
\text { three Nigerians }\end{array}$ & $\begin{array}{l}\text { The suspects } \\
\text { were arrested at } \\
\text { the Agbani area, } \\
\text { near Bakassi } \\
\text { Local } \\
\text { Government } \\
\text { Area, the border } \\
\text { between Nigeria } \\
\text { and Cameroon. }\end{array}$ & $\begin{array}{l}\text { The suspects were } \\
\text { caught with } 134 \\
\text { drums containing } \\
250 \text { litres of petrol } \\
\text { each, and } \\
\text { concealed under } \\
\text { consumer goods. }\end{array}$ & $\begin{array}{l}\text { The suspects were } \\
\text { arrested by Nigerian } \\
\text { Navy handed over the } \\
\text { seven suspects to the } \\
\text { Akwa lbom } \\
\text { Commandant of the } \\
\text { Nigeria Security and } \\
\text { Civil Defence Corps, } \\
\text { for proper investigation } \\
\text { and prosecution }\end{array}$ \\
\hline $\begin{array}{l}\text { December 26, } \\
2013\end{array}$ & MV ECLIPS & $\begin{array}{l}\text { Nine Nigerian } \\
\text { Crew Members. }\end{array}$ & $\begin{array}{l}\text { Obi Creek, } \\
\text { Bayelsa State. }\end{array}$ & $\begin{array}{l}\text { The vessel was } \\
\text { laden with about } \\
870,000 \text { litres of } \\
\text { suspected stolen } \\
\text { crude oil. }\end{array}$ & $\begin{array}{l}\text { The suspect were } \\
\text { arrested Nigerian } \\
\text { Navy and handed } \\
\text { over to the Nigeria } \\
\text { Security and Civil } \\
\text { Defense Corps, } \\
\text { Bayelsa State } \\
\text { command for } \\
\text { prosecution }\end{array}$ \\
\hline $\begin{array}{l}\text { October 23, } \\
2013\end{array}$ & $\begin{array}{l}\text { MT } \\
\text { FRANKESE } \\
\mathrm{N}\end{array}$ & $\begin{array}{l}\text { Three Ghanaians } \\
\text { and nine Nigerians }\end{array}$ & $\begin{array}{l}\text { Akassa } \\
\text { Community in } \\
\text { Brass L.G.A of } \\
\text { Bayelsa state. }\end{array}$ & $\begin{array}{l}\text { Vessel was loaded } \\
\text { with over } 1,092,000 \\
\text { litres of crude oil } \\
\text { suspected to be } \\
\text { stolen. }\end{array}$ & $\begin{array}{l}\text { The suspects were } \\
\text { arrested by Nigerian } \\
\text { Navy and handed over } \\
\text { to the Police } \\
\text { Command in Bayelsa. }\end{array}$ \\
\hline $\begin{array}{l}\text { October 07, } \\
2013\end{array}$ & $\begin{array}{l}\text { Two Vessels: } \\
\text { MILANDROS } \\
\text { and EBBA, } \\
\text { belonging to } \\
\text { PWS } \\
\text { Integrated } \\
\text { Service } \\
\text { Limited. }\end{array}$ & $\begin{array}{l}\text { A Ghanaian and } 25 \\
\text { Nigerians. }\end{array}$ & $\begin{array}{l}\text { Bonny Anchorage } \\
\text { in Rivers State. }\end{array}$ & $\begin{array}{l}\text { The vessel, } \\
\text { MILANDROS, was } \\
\text { intercepted where a } \\
\text { six-inch diameter } \\
\text { hose over a } \\
\text { distance of } 1,000 \\
\text { metres from the } \\
\text { vessel had been } \\
\text { connected to } \\
\text { pipeline, while } \\
\text { EBBA was laden } \\
\text { with } 282 \text { tons of } \\
\text { suspected illegally } \\
\text { distilled diesel }\end{array}$ & $\begin{array}{l}\text { Crew members and } \\
\text { vessels were arrested } \\
\text { the Joint Task Force } \\
\text { (JTF) }\end{array}$ \\
\hline $\begin{array}{l}\text { September 25, } \\
2013 .\end{array}$ & $\begin{array}{l}\text { MV } \\
\text { JEHOVAH } \\
\text { MIRACLE 3" } \\
\text { and a } \\
\text { wooden boat }\end{array}$ & $\begin{array}{l}15 \text { Nigerians on a } \\
\text { saparete raids }\end{array}$ & $\begin{array}{l}\text { Brass River in } \\
\text { Bayelsa State. }\end{array}$ & $\begin{array}{l}\text { The small tug boat } \\
\text { and wooden boat } \\
\text { with } 15 \text { Nigerians } \\
\text { were arrested due } \\
\text { to the lack of proper } \\
\text { permit }\end{array}$ & $\begin{array}{l}\text { The suspects were } \\
\text { arrested Nigerian } \\
\text { Navy and handed } \\
\text { over to the police. }\end{array}$ \\
\hline
\end{tabular}


Table 1. Cont.

\begin{tabular}{|c|c|c|c|c|c|}
\hline $\begin{array}{l}\text { September 16, } \\
2013\end{array}$ & MB LILLY & Eight crew members & $\begin{array}{l}\text { Akassa creek in } \\
\text { Bayelsa State. }\end{array}$ & $\begin{array}{l}\text { Allegedly indulging in } \\
\text { illegal oil bunkering }\end{array}$ & $\begin{array}{l}\text { The crew members } \\
\text { were arrested by Joint } \\
\text { Task Force (JTF). The } \\
\text { barge was towed to } \\
\text { Brass anchorage for } \\
\text { safe custody }\end{array}$ \\
\hline $\begin{array}{l}\text { September 6, } \\
2013\end{array}$ & MT PAULINE & $\begin{array}{l}\text { A Cameroonian and } \\
\text { nine Nigerians }\end{array}$ & $\begin{array}{l}\text { Atlantic fringe of } \\
\text { Brass in Brass } \\
\text { L.G.A of Bayelsa } \\
\text { state }\end{array}$ & $\begin{array}{l}\text { Vessel loaded with } \\
360,000 \text { litres of } \\
\text { illegally refined diesel } \\
\text { suspected to have } \\
\text { been stolen }\end{array}$ & $\begin{array}{l}\text { Crew members and } \\
\text { vessel were arrested by } \\
\text { Nigerian Navy and } \\
\text { handed over to EFCC. }\end{array}$ \\
\hline $\begin{array}{l}\text { September 3, } \\
2013 .\end{array}$ & $\begin{array}{l}\text { Two barges } \\
\text { christened } \\
\text { CWTC16 and } \\
\text { TIKORO2 }\end{array}$ & $11 \mathrm{crew}$ member & $\begin{array}{l}\text { Kasabobo Creek, } \\
\text { Southern ljaw } \\
\text { L.G.A, Bayelsa } \\
\text { State. }\end{array}$ & $\begin{array}{l}\text { Loaded with illegally } \\
\text { sourced crude oil. }\end{array}$ & $\begin{array}{l}\text { Crew members and } \\
\text { barges were arrested by } \\
\text { Joint Task Force (JTF) }\end{array}$ \\
\hline August 26, 2013. & $\begin{array}{l}\text { MV SEA } \\
\text { GIANT }\end{array}$ & $\begin{array}{l}\text { A Cameroonian and } \\
11 \text { Nigerian crew } \\
\text { members }\end{array}$ & $\begin{array}{l}\text { Waterway of the } \\
\text { Egweama } \\
\text { Community in } \\
\text { Brass L.G.A of } \\
\text { Bayelsa State. }\end{array}$ & $\begin{array}{l}\text { Theft of } 10,000 \text { litres } \\
\text { of locally refined } \\
\text { diesel. }\end{array}$ & $\begin{array}{l}\text { Crew members and } \\
\text { vessel were arrested by } \\
\text { Nigerian Navy and } \\
\text { handed over to EFCC. }\end{array}$ \\
\hline August 24, 2013. & $\begin{array}{l}\text { MV } \\
\text { TOBILOBA }\end{array}$ & $\begin{array}{l}\text { Seven Nigerian } \\
\text { Crew Members }\end{array}$ & $\begin{array}{l}\text { Akassa creek in } \\
\text { Bayelsa State. }\end{array}$ & $\begin{array}{l}\text { Vessel laden with } \\
100,000 \text { litres of } \\
\text { illegally refined AGO }\end{array}$ & $\begin{array}{l}\text { Crew members and } \\
\text { vessel were arrested by } \\
\text { Nigerian Navy and } \\
\text { handed over to EFCC }\end{array}$ \\
\hline August 15, 2013. & $\begin{array}{l}\text { MV LILA and } \\
\text { tugboat } \\
\text { christened, } \\
\text { MV St. } \\
\text { VICTORIA }\end{array}$ & $\begin{array}{l}\text { Six suspects were } \\
\text { arrested on the } \\
\text { tugboat }\end{array}$ & $\begin{array}{l}\text { Odioma waterways, } \\
\text { Brass Local } \\
\text { Government Area, } \\
\text { Bayelsa State. }\end{array}$ & $\begin{array}{l}\text { The barge was } \\
\text { carrrying an unknown } \\
\text { quantity of products } \\
\text { suspected to be } \\
\text { stolen crude oil. }\end{array}$ & $\begin{array}{l}\text { Crew members and } \\
\text { vessels were arrested } \\
\text { by Nigerian Navy and } \\
\text { handed over to EFCC. }\end{array}$ \\
\hline August 11, 2013. & $\begin{array}{l}\text { TUG S \& T } \\
\text { VICTORIA }\end{array}$ & Six Crew Members & $\begin{array}{l}\text { Akassa creek in } \\
\text { Bayelsa State. }\end{array}$ & $\begin{array}{l}\text { Salvage operation of } \\
\text { MT LINA }\end{array}$ & $\begin{array}{l}\text { Crew members and } \\
\text { vessels were arrested } \\
\text { by Nigerian Navy and } \\
\text { handed over to EFCC. }\end{array}$ \\
\hline July 25,2013 & MV Henty & $\begin{array}{l}\text { A Ghanaian and five } \\
\text { Nigerians }\end{array}$ & $\begin{array}{l}\text { Egweama, Brass in } \\
\text { Bayelsa state }\end{array}$ & $\begin{array}{l}\text { Illegal conversion } \\
\text { from fishing trawler to } \\
\text { a bunkering vessel } \\
\text { with } 132,000 \text { litres of } \\
\text { illegally refined AGO }\end{array}$ & $\begin{array}{l}\text { Crew members and } \\
\text { vessel were arrested by } \\
\text { Nigerian Navy and } \\
\text { handed over to EFCC. }\end{array}$ \\
\hline July 23, 2013. & $\begin{array}{l}\text { MT RICA and } \\
\text { MT FAVOUR } \\
1\end{array}$ & $\begin{array}{l}14 \text { suspects were } \\
\text { arrested from MT } \\
\text { RICA; nine were } \\
\text { nabbed on MT } \\
\text { FAVOUR } 1\end{array}$ & $\begin{array}{l}\text { MT RICA was } \\
\text { apprehended along } \\
\text { the Nun River while } \\
\text { MT FAVOUR } 1 \text { was } \\
\text { arrested off Akassa } \\
\text { River, Bayelsa } \\
\text { State. }\end{array}$ & $\begin{array}{l}\text { The two vessels, MT } \\
\text { RICA and MT } \\
\text { FAVOUR } 1 \text { were } \\
\text { loaded with } 150,000 \\
\text { and } 100,000 \text { litres } \\
\text { respectively of } \\
\text { illegally refined AGO }\end{array}$ & $\begin{array}{l}\text {.The suspects were } \\
\text { arrested by Nigerian } \\
\text { Navy and handed over } \\
\text { to the police in Yenegoa } \\
\text { for further investigation } \\
\text { and prosecution. }\end{array}$ \\
\hline July 14,2013 & CAPE HOPE & 14 crew members & $\begin{array}{l}\text { Benneth Island in } \\
\text { Warri South Local } \\
\text { Government Area } \\
\text { of Delta State. }\end{array}$ & $\begin{array}{l}\text { Alleged illegal } \\
\text { bunkering and } \\
\text { offering JTF } \\
\text { commander bribe of } \\
\text { N14 million to } \\
\text { facilitate the illegal } \\
\text { deal. }\end{array}$ & $\begin{array}{l}\text { The crew members and } \\
\text { vessel were arrested by } \\
\text { Joint Task Force (JTF). }\end{array}$ \\
\hline July 9, 2013. & $\begin{array}{l}\text { Unregistered } \\
\text { vessel }\end{array}$ & $\begin{array}{l}\text { A traditional ruler } \\
\text { and three other } \\
\text { persons }\end{array}$ & $\begin{array}{l}\text { Along the } \\
\text { waterways of } \\
\text { Akassa in Brass } \\
\text { local government } \\
\text { area of Bayelsa } \\
\text { State. }\end{array}$ & $\begin{array}{l}\text { Stealing 2,000 metric } \\
\text { tonnes of crude oil }\end{array}$ & $\begin{array}{l}\text { The suspects were } \\
\text { arrested by the Joint } \\
\text { Task Force (JTF), }\end{array}$ \\
\hline
\end{tabular}


Table 1. Cont.

\begin{tabular}{|c|c|c|c|c|c|}
\hline July 6, 2013 & $\begin{array}{l}\text { MT WHARF } \\
\text { DALE }\end{array}$ & $\begin{array}{l}\text { Six Nigerian crew } \\
\text { members }\end{array}$ & $\begin{array}{l}\text { Egweama, Brass } \\
\text { in Bayelsa state }\end{array}$ & $\begin{array}{l}\text { Dubious intent to } \\
\text { load stolen crude } \\
\text { and engaged in oil } \\
\text { transport without } \\
\text { flag, registration, } \\
\text { call-sign and } \\
\text { International } \\
\text { Maritime } \\
\text { Organisatio (IMO) } \\
\text { number }\end{array}$ & $\begin{array}{l}\text { Crew members and } \\
\text { vessel were arrested } \\
\text { by Nigerian Navy and } \\
\text { handed over to police. }\end{array}$ \\
\hline June 3, 2013 & MV DALAL & 10 crew members & $\begin{array}{l}\text { Akassa creeks of } \\
\text { Southern ljaw } \\
\text { Local } \\
\text { Government Area } \\
\text { of Bayelsa State. }\end{array}$ & $\begin{array}{l}\text { The vessel was } \\
\text { loaded with } 120,000 \\
\text { litres of illegally } \\
\text { refined AGO } \\
\text { (Automated Gas Oil }\end{array}$ & $\begin{array}{l}\text { Crew members and } \\
\text { vessel were arrested } \\
\text { by Nigerian Navy and } \\
\text { handed over to the } \\
\text { EFCC.. }\end{array}$ \\
\hline May 27,2013 & $\begin{array}{l}\text { ERISHNA } \\
\text { DOLPHIN } \\
\text { and two } \\
\text { barges }\end{array}$ & 11 crew members. & $\begin{array}{l}\text { Obi Creek in } \\
\text { Southern ljaw } \\
\text { Local } \\
\text { Government Area } \\
\text { of Bayelsa State, } \\
\text { Bakana creek } \\
\text { and Abonema } \\
\text { waterfront in } \\
\text { Rivers State }\end{array}$ & $\begin{array}{l}\text { The two barges } \\
\text { were laden with } \\
7,500 \text { and } 500,000 \\
\text { litres of adulterated } \\
\text { Automated Gas Oil } \\
\text { illegally distilled } \\
\text { from stolen crude } \\
\text { oil }\end{array}$ & $\begin{array}{l}\text { The suspects and } \\
\text { barges were arrested } \\
\text { bt the Joint Task } \\
\text { Force (JTF). }\end{array}$ \\
\hline May 22, 2013. & $\begin{array}{l}\text { MT } \\
\text { SWORDFIS } \\
\text { H }\end{array}$ & $\begin{array}{l}\text { Three crew } \\
\text { members, two } \\
\text { staff of the Liberty } \\
\text { Jetty and } 20 \text { other } \\
\text { suspects in } \\
\text { connection with } \\
\text { the oil theft }\end{array}$ & $\begin{array}{l}\text { Liberty Jetty } \\
\text { Elegbata, Marina, } \\
\text { Lagos, }\end{array}$ & $\begin{array}{l}\text { The vessel was } \\
\text { used for oil theft. } \\
\text { The vessel was } \\
\text { loaded with } \\
\text { unspecified amount } \\
\text { of crude oil } \\
\text { suspected to have } \\
\text { been stolen }\end{array}$ & $\begin{array}{l}\text { Suspects and vessel } \\
\text { were arrested by The } \\
\text { Nigerian Army and } \\
\text { handed over to the } \\
\text { Economic and } \\
\text { Financial Crimes } \\
\text { Commission, EFCC, } \\
\text { for prosecution. }\end{array}$ \\
\hline May 3, 2013 & $\begin{array}{l}\text { EMPTY V- } \\
\text { LAND }\end{array}$ & 10 crew members & $\begin{array}{l}\text { The high sea of } \\
\text { Bonny in Rivers } \\
\text { State }\end{array}$ & $\begin{array}{l}\text { The vessel was } \\
\text { carrying stolen } \\
\text { crude oil of about } \\
1,300 \text { metric tones }\end{array}$ & $\begin{array}{l}\text { Vessel and crew } \\
\text { members were } \\
\text { arrested by Nigerian } \\
\text { Navy handed over to } \\
\text { FOB Bonny }\end{array}$ \\
\hline $\begin{array}{l}\text { January 26, } \\
2013 .\end{array}$ & MT ASHKAY & $\begin{array}{l}10 \text { Indians and two } \\
\text { Ghanaians }\end{array}$ & $\begin{array}{l}\text { Sangana River, } \\
\text { near Port } \\
\text { Harcourt in } \\
\text { Rivers State. }\end{array}$ & $\begin{array}{l}\text { The vessel was } \\
\text { laden with } 157,822 \\
\text { litres of stolen } \\
\text { crude. }\end{array}$ & $\begin{array}{l}\text { The suspects were } \\
\text { arrested by Nigerian } \\
\text { Navy and handed } \\
\text { over to EFCC for } \\
\text { investigation and } \\
\text { prosecution }\end{array}$ \\
\hline $\begin{array}{l}\text { December 29, } \\
2012\end{array}$ & $\begin{array}{l}\text { MT } \\
\text { ATLANTIC } \\
\text { STAR }\end{array}$ & $\begin{array}{l}\text { Nine Crew } \\
\text { Members. }\end{array}$ & $\begin{array}{l}\text { The coast of } \\
\text { Bonny Island in } \\
\text { Rivers State. }\end{array}$ & $\begin{array}{l}\text { The vessel loaded } \\
\text { with } 1,000 \text { tonnes } \\
\text { of stolen crude oil } \\
\text { was arrested while } \\
\text { illegally siphoning } \\
\text { crude oil from a } \\
\text { pipeline }\end{array}$ & $\begin{array}{l}\text { The suspects were } \\
\text { arrested by (JTF) and } \\
\text { handed over to } \\
\text { Nigerian Security and } \\
\text { Civil Defence Corps } \\
\text { for prosecution. }\end{array}$ \\
\hline $\begin{array}{l}\text { October } 17 \text { \& } \\
18,2012\end{array}$ & $\begin{array}{l}\text { MT LADY } \\
\text { THERESA } \\
\text { and PECOS } \\
\text { PETERS }\end{array}$ & $\begin{array}{l}10 \text { Nigerian crew } \\
\text { members }\end{array}$ & $\begin{array}{l}\text { LightHouse, } \\
\text { Bonny River, } \\
\text { Bonny Local } \\
\text { Government Area } \\
\text { of Rivers State. }\end{array}$ & $\begin{array}{l}\text { The two illegal } \\
\text { bunkering vessels } \\
\text { containing } 300,000 \\
\text { litres of diesel were } \\
\text { caught siphoning } \\
\text { illegally-refined } \\
\text { petroleum product } \\
\text { from a barge. }\end{array}$ & $\begin{array}{l}\text { The crew members } \\
\text { were arrested by Joint } \\
\text { Task Force (JTF) and } \\
\text { handed over to the } \\
\text { police. }\end{array}$ \\
\hline
\end{tabular}


Table 1. Cont.

\begin{tabular}{|c|c|c|c|c|c|}
\hline October 5, 2012 & $\begin{array}{l}\text { Seven } \\
\text { barges }\end{array}$ & $\begin{array}{l}20 \text { Ghanaians and } \\
\text { six Nigerians }\end{array}$ & $\begin{array}{l}\text { Barges were } \\
\text { impounded in } \\
\text { Abonnema, } \\
\text { Akuku-Toru } \\
\text { Local } \\
\text { Government } \\
\text { Area of Rivers } \\
\text { State. }\end{array}$ & $\begin{array}{l}\text { Alleged illegal } \\
\text { bunkering. The } \\
\text { seven barges were } \\
\text { loaded with crude } \\
\text { oil }\end{array}$ & $\begin{array}{l}\text { The seven barges } \\
\text { were destroyed while } \\
\text { the suspects were } \\
\text { arrested by Joint } \\
\text { Task Force (JTF) and } \\
\text { handed over to the } \\
\text { Nigeria Security and } \\
\text { Civil Defence Corps } \\
\text { (NSCDC), for } \\
\text { prosecution. }\end{array}$ \\
\hline June 19, 2012. & $\begin{array}{l}\text { "MT ST } \\
\text { VANESSA }\end{array}$ & $\begin{array}{l}\text { Nine Filipinos and } \\
\text { six Romanians }\end{array}$ & $\begin{array}{l}45 \text { nautical miles } \\
\text { off Akassa in } \\
\text { Bayelsa State. }\end{array}$ & $\begin{array}{l}\text { suspicious activities } \\
\text { and loitering } \\
\text { around Akassa- } \\
\text { Brass for about two } \\
\text { weeks, without } \\
\text { clear and specific } \\
\text { mission }\end{array}$ & $\begin{array}{l}\text { The } 15 \text { expatriates } \\
\text { and the vessel were } \\
\text { arrested by the } \\
\text { Nigerian Navy and } \\
\text { handed over to the } \\
\text { police in Port } \\
\text { Harcourt and Bonny } \\
\text { Island }\end{array}$ \\
\hline May 09, 2012 . & $\begin{array}{l}\text { MT ANI and } \\
\text { MT OSO }\end{array}$ & $\begin{array}{l}21 \text { Ghanaians and } \\
\text { five Nigerians }\end{array}$ & $\begin{array}{l}\text { Sombeiro River } \\
\text { in the South- } \\
\text { Eastern part of } \\
\text { Degema Local } \\
\text { Government } \\
\text { Area of Rivers } \\
\text { State. }\end{array}$ & $\begin{array}{l}\text { The Vessels were } \\
\text { arrested with } \\
650,000 \text { metric } \\
\text { tonnes of stolen } \\
\text { crude oil. }\end{array}$ & $\begin{array}{l}\text { The vessels were } \\
\text { destroyed by the } \\
\text { security outfit, Joint } \\
\text { Task Force (JTF). }\end{array}$ \\
\hline $\begin{array}{l}\text { November 01, } \\
2011\end{array}$ & $\begin{array}{l}\text { MV } \\
\text { OMIESAM } \\
\text { and several } \\
\text { Cotonu } \\
\text { boats }\end{array}$ & $\begin{array}{l}\text { Vessel has a crew } \\
\text { of eight and the } \\
\text { other } 38 \text { suspects } \\
\text { were found with } \\
13 \text { Cotonou boats } \\
\text { and } 1 \text { speed boats } \\
\text { that had } \\
\text { assembled beside } \\
\text { the vessel }\end{array}$ & $\begin{array}{l}\text { Akassa enclave } \\
\text { on the Atlantic } \\
\text { fringe of Brass, } \\
\text { Bayelsa State. }\end{array}$ & $\begin{array}{l}\text { The Vessel was } \\
\text { arrested while } \\
\text { receiving illegally } \\
\text { refined petroleum } \\
\text { products from the } \\
\text { Cotonu boats }\end{array}$ & $\begin{array}{l}\text { The vessel MV } \\
\text { Omiesam and its } \\
\text { eight man crew were } \\
\text { arrested and escorted } \\
\text { to Government Jetty } \\
\text { Yenagoa by Joint } \\
\text { Task Force (JTF). }\end{array}$ \\
\hline January 6,2009. & $\begin{array}{l}\text { SANDRA } \\
\text { VALLETTA } \\
\text { LAGOS }\end{array}$ & $\begin{array}{l}\text { Six Ghanaians } \\
\text { and a Nigerian }\end{array}$ & $\begin{array}{l}\text { Chanomi Creeks } \\
\text { of Warri South } \\
\text { West Local } \\
\text { Government } \\
\text { Area of Delta } \\
\text { State. }\end{array}$ & $\begin{array}{l}\text { The vessel was } \\
\text { loaded with } 4,000 \\
\text { metric tonnes of } \\
\text { illegally bunkered } \\
\text { crude oil worth } \\
\text { about } \$ 1.17 \text { million }\end{array}$ & $\begin{array}{l}\text { The suspects were } \\
\text { paraded by the Joint } \\
\text { Task Force (JTF) in } \\
\text { Warri, Delta State. }\end{array}$ \\
\hline
\end{tabular}

Source: Author's compilation from media sources, 2015

challenges no matter what the challenge is (Iredia, 2011).

On a wider scope, national security may be too complex to be captured in one definition because of its meaning in content and implications. However, national security encompasses the sum of what a nation does in order to safeguard itself as a sovereign entity and this includes every aspect of a nation's life and existence. It then means that national security of a nation can extend to the well-being of its citizens, institutions, interests, development plans, economy etc. Apart from these, it also involves the physical protection of a nation's subjects, landscape and independence and even issues such as food security and national image (Okoroafor, Nzenwa and Oti, 2012)

\section{Implications of Oil Theft on Nigeria's National Security}

Crude oil phenomenon has led to a continued proliferation of small arms and light weapons (SALWs) in the Niger Delta; it has ignited and exacerbated many inter-ethnic conflicts among the people as well as created a general sense of insecurity in the entire region. Many of the arms in circulation in the Niger Delta, including a variety of sophisticated weapons, have been purchased with money derived directly or indirectly from illegal bunkering. Insecurity in some parts of the country results in part, from accessibility of oil-purchased arms with illegal bunkering serving as a major contributor to 
Nigeria's violent crime, armed robbery, piracy and kidnapping (Onwuemenyi, 2012).

The social and security implications of all these include the destruction of the economy of communities, arms proliferation, increased attraction to crimes, higher incidence of school drop-outs, increased inflow of migrant workers to service the illegal business and the consequences of militarisation of communities. All these negative impacts have long-term implications that may take generations to reverse if at all possible (Igbuku, 2014). Similary, Katsouris and Sayne (2013) noted that oil theft has been the major cause of violent conflict in the Niger Delta. Most of the oil theft actors exchange the crude oil for heavy arms at the high sea, while others use the proceeds to import arms into the region, with the principal aim of using the arms to secure their illegal activities in the region. The arms are used for attacks and counter attacks from different gang groups and security agents, as every group is bound to have adequate arms and be gun-battle ready to enable them remain in the business. This has resulted in proliferation of small and heavy arms in the region, leading to constant attacks and counter attacks by different groups, and insecurity of lives and properties in the region (Wilson, 2014).

The insecurity provides the enabling ground for kidnapping activities of expatriates, oil and top government workers for financial ransom in the region. Wilson (2014) observed that:

"The violence and crisis occasioned by the oil theft activities in the Niger Delta region is spreading speedily to other parts of Nigeria and beyond. Firstly, with the heavy arms in the possession of the youths and the constant attacks on oil and non oil facilities for economic benefits of the actors, youths from other geo-political regions see the oil theft activities as very lucrative and are recruited into oil theft activities as a means of economic empowerment. The same youths irrespective of geo-political region of origin are empowered with heavy arms and they use same to cause violence in different parts of the country, they are also sometimes used by the politicians to either attack political opponents or rig elections, thereby increasing the insecurity challenge of the nation. Secondly, larger part of the oil theft is carried out in the high seas and oil export terminals, thereby increasing the activities of the sea pirates in the sub-region".

The sea pirates also benefit from the oil theft, thereby resulting to the escalation of sea pirate activities in the waterways, and bridging free movement of goods and services in the sub-region. The pirates attack oil investors and their investments, while the state security agents give counter attack to the pirates, thereby leading to constant violence and attacks in the West African waterways. This violence perpetuated by the oil theft actors and sea pirates is threatening the peace and security of the West African States, particularly those along the coastal areas, where the oil vessels pass through to Europe, America and Asia (Wilson, 2014).

Oil theft that has led to piracy and criminal activities in the Niger Delta create insecurity and breach of the peace that are likely to affect legitimate social and economic activities in the country. These problems also have the very damaging consequence of giving the signal to the rest of the international community that Nigeria is not a safe and secure place and as such not suitable for economic investment and activities. This is particularly important in view of the efforts being made to create the desired atmosphere to attract foreign investment. However, it should be noted that insecurity, especially in the Niger Delta subregion is not a problem that is unique to Nigeria. The US, the UK and many other countries, face the challenges of insecurity within their borders on a daily basis. The difference between them and our country, Nigeria is how they manage the threats; how knowledgeable and prepared they are; how they deploy resources against the threats; how effective they are; how patriotic and united these people are against threats of insecurity (Adejumo, 2011).

On the other hand, it is the increasing deterioration of the capability of the Nigerian Military and Security Forces to secure Nigeria internally and externally that constitutes the crises of Nigeria's present insecurity. It is the consequences of the failing capability of the Nigerian Military and Security Forces to conquer and subdue privately armed groups who have become "proto states" in their own right. In all, what we need is a good government with strong political will and determination to tackle the challenges of insecurity in the Niger Delta in particular and Nigeria in general. However, it should be noted that a good government is possible in as much as people who are in positions of authority are committed to the discharge of their duties; are determined to serve with zeal and patriotism; and are ready to stand by the truth and die for it (Adejumo, 2011).

\section{Attempts at Tackling Oil Theft by the Government}

In recognition of the socio-economic and security threat that crude oil theft poses to Nigeria's corporate existence, a number of initiatives were embarked upon by the successive governments in Nigeria directed at tackling oil theft in the Niger Delta. Such initiatives include; increased enforcement measures against the maritime trade in stolen oil which involved the Nigerian Navy being tasked with the responsibility for registration of vessels in Nigerian waters, a measure which was to be accompanied by increased prosecution of transgressors, the establishment of a task force on national strategic infrastructure intended to monitor and respond to oil theft, the establishment of a special security outfit and militarization of the Niger Delta region, the introduction of the Nigerian Extractive Industries Transparency Initiative, 
closing markets for illegal oil, a hotline for reporting oil theft, granting of amnesty to Niger Delta militants and enforcement and public education efforts against artisanal refining in the Niger Delta region.

During the president Yar Adua administration (20072009), the attacks on oil installations, kidnapping of oil workers by the militants and illegal oil bunkering became escalated further. In a bid to curb oil theft and other vices in the Niger Delta, former late President Yar Adua initiated the Amnesty programme to the Niger Delta militant. He also awarded security contracts to ex-militant war lords. For instance, Tompolo, after accepting Federal Government amnesty on June 27, 2009 by late President Umaru Musa Yar'Adua, was awarded an annual security contract that is worth $\$ 22.5$ million to assist the government in curbing crude oil theft. Dokubo is allegedly collecting $\$ 9$ million annually for the protection of some pipelines in Rivers State, while 'General' Ateke Toms and 'General' Ebikabowei Boyloaf Victor Ben collect \$3.5 million each (Nation, 2012). Despite the huge contracts, crude oil theft has increased geometrically over few years. While crude oil theft has remained a global issue, it has continued unabated in Nigeria with no immediate solution in sight (Dodondawa, 2014; Ebiri, 2014).

The administration of President Goodluck Jonathan (2009 to 2015) also responded in different ways to quell the menace of oil theft. The president has reached out to some of his counterparts in various countries where government feels some of Nigeria's crude are being refined in, and where these entities are laundering the funds made as a result of illegal bunkering. President Goodluck Jonathan earlier in the 2014 approached the European Union and the United States for support by not purchasing stolen crude oil from Nigeria (Dodondawa, 2014; Nwanosike, 2013; Udo, 2013). Recently, President Goodluck has taken some initiatives and steps to curb the menace.

The initiatives include the setting aside of N15 billion for the purchase of security equipment to checkmate the scourge of oil theft in the Niger Delta approved by the National Economic Council (NEC); utilisation of new technology and Radar Surveillance to boost maritime security and increase sea patrol by the Nigerian Navy; inauguration of an Inter-Agency Maritime Operations Coordination Committee (IMOCC) to provide synergy among agencies operating in the industry to ensure safety and security in the Nigerian maritime industry; provision of air surveillance of Nigeria's pipelines with

modern aircraft manned by Nigerian pilots trained under the Petroleum Technology Development Fund (PTDF) programme (Izuora, 2014).

President Goodluck Jonathan had also revealed that the Federal Government earmarked \$1billion for the implementation of a comprehensive programme to check crude oil theft, the vandalism of oil and gas infrastructure, and the apprehension and prosecution of crude oil thieves (Agba, 2014; Dodondawa, 2014). The President also set up a technical committee in March 2014, to look into all aspects of the implementation of the programme, which will include further action to enhance the security of pipelines and other oil industry infrastructure, resolve community-related issues, boost youth empowerment in oil-producing areas and enhance the commitment of oil companies to the discharge of their corporate social responsibilities. But four months after the announcement by the President, members of the committee remain unknown while the timeframe for submission of their report is yet to be made public (Dodondawa, 2014).

The import of the foregoing is that the upsurge of oil theft in recent times clearly indicates that the previous attempts by the Nigerian government to address the problem have not yielded a remarkable positive result. There are fears among stakeholders and security experts in the industry that crude oil theft in Nigeria may persist for long time to come due to level of sophistication the illicit trade has assumed in recent times and the caliber of persons involved in it even from within and outside the country (Uwotu, 2013). Consequently, the Federal Government in conjunction with major stakeholders in the industry, mostly, international oil companies, host communities, security personnel, civil society organizations amongst others have to strategize on the best method to adopt in putting an end to the menace of oil theft in the Niger Delta

\section{Concluding Remarks and Recommendations}

The importance of oil to Nigeria's security, economic survival and political stability cannot be overemphasized as the nation depends majorly on oil revenue for her economic survival. The recent increase in oil theft, illegal bunkering, piracy and other forms of criminality in the Niger Delta suggests that the fragile peace established by the amnesty programme is now at risk, and the region seems to be sliding back into instability. The apparent insoluble instability in the Niger Delta, even in its postamnesty phase, is a sort of retribution for decades of abuse of the land and people of the Niger Delta (Okoli, 2013).

The increase of crude oil theft and illegal bunkering in the Niger Delta is a threat to economic viability of Nigeria and a challenge that is critical to the wellbeing of the industry that drives the Nigerian economy. Except drastic action is taken to address the Niger Delta crisis and put an end to oil theft in the region, the Nigerian economy will be heading for a doom and this will pose a grave consequences to Nigeria's national security and economic survival. In line with this, the following are recommendations we have put forth:

The stolen oil trade problem must be tackled at its source which is unemployment and poverty. There must be a partnership between the Nigerian government and the international community to invest more and expand 
the legitimate oil sector. This would provide more opportunities for the local community which could benefit from their region's rich oil resources without resorting to theft. Legitimizing and improving many of the illegal oil refineries by bringing them under the management of oil companies could also be a viable option (Sun, 2013).

A comprehensive solution that would greatly limit the illegal activities concerning the oil industry in Nigeria by addressing the root of the problem is to invest in development projects that utilize the skills of the bunkerers. By providing legal alternatives in the form of job opportunities compatible with their skill-sets, illegal activities will decrease. For instance, investment in local refineries would create a job pool for the bunkerers as well as limiting the country's need to import fuel (ElSalmy, 2014).

Government should allocate adequate resources; technology, equipment and logistics to security agencies; the Navy, the Joint Task Force, Nigeria Maritime Administration and Safety Agency, Nigeria Security and Civil Defense Corp, and other security operatives working in the Niger Delta region to enable them function effectively in combating oil thieves and maintaining security. The security agencies should also tap into regional and global security structures, with the support of other governments which will pave way for tracking and intercepting the illicit cargoes of stolen oil to and from the Gulf of Guinea.

The fight against oil theft and illegal bunkering requires a multi-faceted approach that takes on broad stakeholders and governments at all levels. Concerted action is urgently needed at the local, national, regional and international levels to address the menace of crude oil theft. Therefore, Nigeria government should collaborate with other countries and international communities suspected to be patronizing her stolen oil on new international laws to regulate the oil movement from one country to the other. The international financial flows and networks which profit from these activities need to be traced, understood and targeted

\section{REFERENCES}

Adejumo AA (2011). "The Problems and Challenges of Insecurity in Nigeria" News diary online, December 16. Available online: http://newsdiaryonline.com/ tok security.html

Afinotan LA, Ojakorotu V (2009). "The Niger Delta Crisis: Issues, Challenges and Prospects." African Journal of Political Science and International Relations, Vol.3 (5), 191- 198.

Agba G (2014). "FG to Tackle Crude Oil Theft With \$1bn - Jonathan" Leadership

Newspaper, Available online: http:// leadership.ng /news/358755/fgtackle-crude-oil-theft-1bn-jonathan

Akpomera E (2013). "International Crude oil theft: the Elite Predatory tendencies in Nigeria." Rivers Journal of Social Studies, Vol. 8, October. pp. 288-299

Akpan U (2013). "Indigenous Operators Express Worry as Cost of Oil Theft hits N15.66n." National Mirror, November 12.

Amanze- Nwachukua (2013). "Crude Theft Threatens Nigeria's 2020 Oil Production, Reserves Targets." Thisday July 30. Available online: www.thisdaylivecom/articles.

Aminu SA (2013). "The Militancy in the Oil Rich Niger Delta: Failure of the Federal Government of Nigeria." Interdisciplinary Journal of Contemporary Research in Business, Vol. 4 (11).

Azuatalam C (2013). "Navy impounds vessel with 'stolen' crude oil."

Nation, May 8. http://thenationonlineng.net/new/navy-impounds-vesselwith-stolen-crude-oil/

Badmus IA (2010). "Oiling the Guns and Gunning for Oil: Oil Violence, Arms Proliferation and the Destruction of Nigeria's Niger-Delta." Journal of Alternative Perspectives in the Social Sciences. 2(1), 323363.

Dodondawa T (2014). "Oil Theft: Nigeria's \$20bn per annum cesspit." Nigerian Tribune,Available online: http://tribune.com.ng/ business/item/13099-oil-theft-nigerias-20bn-per-annum-cesspit.

Ebiri K (2014). "Economic Insurgency: Why Oil Theft, Illegal Bunkering Persist.The Guardian, February 4.

El-Salmy A (2014). "Oil Theft in Nigeria." The American University in Cairo. Retrieved on

August 20, 2014 from http://www.aucegypt.edu/huss/pols/Khamasin Pages/article.aspx?eid $=12$

Ejovi A, Ebie CS (2013)."Niger Delta: A Critical Appraisal of the Amnesty Programme and Social Political Development in Nigeria." Research on Humanities and Social Sciences, Vol.3 (22), 130-137

Fagbadebo MO, Akinola OA (2010). "Post-Amnesty Niger Delta and the Promise of Development: Issues, Prospects and Problems." From the Selected Works of Omololu Michael Fagbadebo, Available online: http://works.bepress.com /otomololu/2.

Garuba DS (2010). "Trans-Border Economic Crimes: Illegal Oil Bunkering and Economic Reforms in Nigeria". Policy Brief Series, No. 15, October. Global Consortium on Security Transformation. Retrieved on May 10, 2014 from www. Securitytransformation. org/gc publications.

Garuba D (2013). "Combating Oil Theft to Redress Budget Deficits in Nigeria." Natural Resource Governance Institute, www.revenuewatch.org

Hinshaw D (2012). "Niger Delta Amnesty Program Fails to End Militancy." The Wall Street Journal. September 4.

Human Rights Watch (2003). "The Warri Crisis: Fueling Violence." Vol. 15, No 18, New York: Human Rights Watch.

Ibaba IS (2011). "Amnesty and Peace - Building in the Niger Delta. Addressing the Frustration - Aggression Trap." African: The Niger Delta (Special Issue) 5(1) 238-271.

Igbuku A (2014). "Crude Oil Theft and Illegal Refining in the Niger Delta." Delta State Oil and Gas Stakeholders' Conference, Tuesday, April 15, 2014. Retrieved August 20, 2014 from http://reformeronline.com/crude-oil-theft-and-illegal-refining- in-theniger-delta/

Ikelegbe A (2005). "The Political Economy of Conflict in the Oil Rich Niger Delta Region of Nigeria." Nordic Journal of African Studies, 14, (2): 208-234.

Ikein A (2009). "The Potential Power of West African Oil to the Economics and Energy Security Interest of Euro- America in the 21st century."Journal of Sustainable Development in Africa, 10(4), 540556.

Iredia T (2011). "What is national security? Vanguard, December 18. Available online: http://www.vanguardngr.com/2011/12/what-isnational-security/

IRIN (2013). "Nigeria: Rising Niger Delta Oil Theft Threatens Security." IRIN News.

Izuora C. (2014). "Nigeria Lost N1.72trn to Oil Theft In 2013 - NNPC." Leadership

Newspaper, March 19. Available online: http://leadership. ng/news/356877 /nigeria-lost-n1-72trn-oil-theft-2013-nnpc

Katsouris C, Sayne A (2013)."Nigeria's Criminal Crude: International Options to Combat the Export of Stolen Oil". London: Chatham House.

Kimiebi IE (2010). "Oil, Militancy and Political Opportunities in Niger Delta." Retrieved on 20/08/2014 from http://kimiebi.blogspot.com

Mernyi D (2014). "Crude Oil Theft, Pipeline Vandalism Cross Over to 2014." The Sun, January 1. Retrieved February 28, 2014 from http://sunnewsonline. com/new/ specials/abuja-metro/crude -oiltheft-pipeline- vandalism-cross-2014/

Nation (2012). "Outrage over N5.6bn Contract for Asari, Ateke, Tompolo." Nation, August 25. Retrieved on July 25, 2014 from 
http://www.the nationonlineng.net/2011/news/59001- outrage-overn5-6bn-contracts-for-asariateke-tompolo

Nwanosike S (2013). "illegal Oil Bunkering: Matters Arising." The Tide. Available online: www.thetide.com

Odemwingie E, Nda-Isaiah J (2013). "Nigeria Loses 400,000 Barrels Daily To Crude Oil Theft-Sentate." Leadership, November 14.

Odunlami T, Mohammed H, Hamza I, Edozie V (2013). "Top politicians, general smile as oil theft cripples Nigeria." Sunday Trust, June 30. Retieved on

August 28 (2014) from http://sundaytrust.com.ng/index.php/top- stories 13537-top-politicians-generals-smile-as-oil-theft-cripples-nigeria

Ogodo D (2012). "Oil Bunkering in the Niger Delta." Nigeria's Oil \& Gas. Available online: www.nigerianoilgas.com/oil.bunkering-in-the-nigerdelta

Okere R (2013). "Curtailing Oil Theft, Illegal Bunkering via Legislation." The Guardian August 21.

Okoroafor EC, Nzenwa BN, Oti BI (2012). "Democracy and National Security:Exploring the Synergy for Good Governance in Nigeria." Journal of Research and Development, Vol. 4 (1), 135-148

Olusola B (2013). "When will Nigeria stop the Crude Oil Theft." Business Day. October 17.

Onwuemenyi $O$ (2012). "Oil bunkering undermining Nigerian economy."Vanguard Retrieved on November 29, 2013 from www.vanguardngr.com./2012/06.

Sun K (2013). "Oil Theft in Nigeria." Retrieved August 2o, 2014 from http://www.ocnus.net /artman2/publish /Africa_8/Oil-Theft-inNigeria.shtml
Tomas M (2010). "Militancy in the Niger Delta." University of Pittsburgh. Udo B (2013). "Nigeria Lost \#1.85 trillion to crude oil theft, sabotage in three years- NEITI." Premium Times, July 30.

Uwotu K (2013). "Does Nigerian Government Have the Political Will to Combat Oil Theft?. Retrieved August 28, 2014 from http://www.aan.network.org.

Wikipedia (2015). "National Security." Retrieved January 6, 2015 from www.wikipedia.org /wiki/ National Security

Wilson G (2014). "The Nigerian State and Oil Theft in the Niger Delta Region of Nigeria." Journal of Sustainable Development in Africa. Vol. 16 (1), 69-81. 